Sains Malaysiana 47(3)(2018): 447-455

http://dx.doi.org/10.17576/jsm-2018-4703-04

\title{
Carbon Stock and Sequestration Valuation in a Mixed \\ Dipterocarp Forest of Malaysia
}

(Penilaian Stok Karbon dan Pensekuesteran dalam Hutan Campuran Dipterokarpa di Malaysia)

\begin{abstract}
NitANAN Koshy MATTHEW, AHMAD SHUIB*, ISMAIL MUHAMMAD, MUHD EKHZARIZAL MOHD EusOP, SRIDAR RAmachandran, SyAmSUl HERMAn MOHAMmAD AFANDI \& ZAITON SAMDin
\end{abstract}

\begin{abstract}
Forest degradation and deforestation are some of the major global concerns as they can reduce the forest carbon stock and sequestration capacity. However, the carbon stock and sequestration potential in a mixed dipterocarp tropical forest remains unclear due to a lack of information. This study was carried out on the carbon stock and estimated its economic value to justify its conservation. Six plots were established in the Endau Rompin National Park, Johor and subplots measuring $50 \times 20 \mathrm{~m}$ were established in each plot. All trees greater than $15 \mathrm{~cm} \mathrm{DBH}$ (diameter at breast height) were identified and the parameters measured included tree height and diameter. The aboveground carbon (AGC) content was about $222 \mathrm{Mg}(C) h \mathrm{a}^{-1}$, belowground carbon $(B G C)$ was $53 \mathrm{Mg}(C) h a^{-1}$ and it was $6 \mathrm{Mg}(C)$ ha-1 for other components. In total, the carbon stock amounted to $\left.281 \mathrm{Mg}^{\mathrm{C}} \mathrm{C}\right) \mathrm{ha}^{-1}$. On the other hand, the total $\mathrm{CO}^{2}$ sequestrated in the mixed dipterocarp forest amounted to 1,040 t $\mathrm{CO}^{2} \mathrm{ha}^{-1}$. The carbon value was estimated at $R M 32,240$ t $\mathrm{CO}^{2} \mathrm{ha}^{-1}$ or $\$ 7,280 \mathrm{tCO}$ $\mathrm{ha}^{-1}$. Therefore, the study found that the dipterocarp forest should be preserved to mitigate greenhouse gas emissions.
\end{abstract}

Keywords: Carbon sequestration; conservation; dipterocarp forest; forest carbon; valuation

\section{ABSTRAK}

Degradasi hutan dan penyahhutanan merupakan masalah global utama kerana ia boleh menurunkan penyimpanan karbon hutan dan kapasiti pensekuesteran. Walau bagaimanapun, penyimpanan karbon dan potensi pensekuesteran dalam hutan tropika dipterokarpa campuran masih tidak jelas kerana kekurangan informasi berkaitannya. Kajian ini dijalankan ke atas simpanan karbon dan anggaran nilai ekonominya untuk memberi justifikasi pemeliharaannya. Enam plot diwujudkan di Taman Negara Endau Rompin, Johor dan subplot berukuran $50 \times 20$ m diwujudkan di setiap plot. Semua pokok yang lebih tinggi daripada $15 \mathrm{~cm}$ DBH (diameter aras dada) telah dikenal pasti dan parameter yang diukur termasuk panjang dan diameter pokok. Kandungan karbon atas tanah (AGC) adalah $222 \mathrm{Mg}(\mathrm{C}) \mathrm{ha}{ }^{-1}, \mathrm{karbon}$ bawah tanah $(B G C)$ adalah $53 \mathrm{Mg}(C)$ hal dan $6 \mathrm{Mg}(C)$ ha-1 untuk komponen lain. Secara keseluruhannya, simpanan karbon terkumpul adalah $281 \mathrm{Mg}(\mathrm{C}) \mathrm{ha}^{-1}$. Sementara itu, jumlah $\mathrm{CO}^{2}$ tersekuestera dalam hutan dipterokarpa campuran berjumlah 1,040 $\mathrm{CO}^{2} \mathrm{ha}^{-1}$. Nilai karbon dianggarkan sebanyak RM32,240 t $\mathrm{CO}^{2} \mathrm{ha}^{-1}$ atau \$7,280 T CO $\mathrm{ha}^{-1}$. Oleh itu, kajian ini menunjukkan bahawa hutan dipterokarpa patut dipelihara untuk mengurangkan pengeluaran gas rumah hijau.

Kata kunci: Hutan dipterokarpa; karbon hutan; pemuliharaan; penilaian; pensekuesteran hutan

\section{INTRODUCTION}

Forests are universally vital as reservoirs, sources of materials, and commodities, as well as sinks for carbon. In fact, forests store large amounts of carbon in the wood and roots of their trees. Studies have estimated that up to $20 \%$ of annual greenhouse gas (GHG) emissions were triggered by carbon sinks, modifications and loss of forests due to natural and anthropogenic disturbances worldwide (Omar $\&$ Hamzah 2012). Therefore, the estimation of biomass and carbon is crucial for the purpose of forest conservation. Following that, forest degradation and deforestation has become a portion of the major worldwide concern. In light of this, studies have also shown that deforestation and forest degradation have accounted for $20 \%$ of global anthropogenic greenhouse gas emissions since the 1990s
(Gullison et al. 2007). In 1990, the world had 4.128 billion hectares of forest; in 2015, however, this total area decreased to 3.999 billion hectares. Therefore, forest degradation and deforestation reduced the limit of forest carbon stockpiling and sequestration as a consequence (Kueh et al. 2013).

On the same note, studies in Southeast Asia have shown that forests have become an important focus of global climate change abatement efforts (Uryu et al. 2008). Data on trends in living forest biomass (2000-2015) showed that there was a decrease from 54,539 million tonnes in 1990 to 43,392 million tonnes in 2015, which is a reduction of 11,147 million tonnes or $20 \%$. Similarly, the carbon stock in living forest biomass recorded a reduction as well, with a decline from 26,281 million ha in 1990 to 
21,121 million ha in 2015 . Hence, the difference amounted to 5,160 million ha or a $20 \%$ reduction rate (FAO 2015).

In relation to that, the carbon sequestration function of forests has become a great concern due to the phenomenon of global warming (Ninan \& Inoue 2013). Carbon sequestration is a term, which describes that process which removes carbon dioxide from the atmosphere. Through photosynthesis, plants absorb carbon dioxide from the atmosphere and store the carbon. In addition to that, plants use sunlight to convert $\mathrm{CO}^{2}$, water and nutrients into sugars and carbohydrates, which accumulate in leaves, twigs, stems and roots. Furthermore, plants also respire, releasing $\mathrm{CO}^{2}$. During this respiratory process, plants also utilise oxygen to maintain life and emit $\mathrm{CO}^{2}$ in the process. At times (e.g. at night and during winter seasons in nontropical climates) living, growing forests are net emitters of $\mathrm{CO}^{2}$, although they are generally net carbon sinks over the life of the forest. Nonetheless, the carbon content varies accordingly based on the type of forests (Busch \& Engelmann 2016). For example, global carbon stocks in vegetation and carbon pools down to a depth of $1 \mathrm{~m}$ shows that the average carbon stocks for various biomass for 109 tonnes per acre that was almost twice less than compared to boreal forests, which was thrice less than in wetlands (Gorte 2009).

In the Malaysian context, the variations in forest types can be categorised into dry inland, swamp and mangrove forests. Examples of dry inland forests are Montane Ericaceous Forests, Montane-Oak Forests, Hill Dipterocarp Forests and Lowland Dipterocarp Forests. On the other hand, the rest are comprised of the Peat Swamp Forests and Mangrove forests (Forestry Department Peninsular Malaysia 2016). In total, 15.73 million ha belong to dry inland forests, 1.48 million ha belong to swamp forests whilst mangrove forests consist of 0.56 million ha. Following that, in Malaysia, per se, limited studies have divulged the carbon stock contained in Dipterocarop dominated forests (Dirocco 2012; Hamdan et al. 2014; Niiyama et al.2010). This underestimates the importance of carbon in mitigating the global warming and, as well, its role in carbon sequestration. In regards to that, research on carbon has extended not to the limits of determining only the carbon stock in trees, but rather also to other strata, such as understory vegetation, the litter layer, and soil, to derive at a more holistic picture of the carbon contained in the forests (Komiyama et al. 2008; Lasco et al. 2016; Nghiem 2014; Niiyama et al. 2010; Saner et al. 2012; Siwar et al. 2016; Wang \& Wesche 2016).

Furthermore, the carbon in forests may be compared in regards to the different types of forests in Malaysia due to different altitudes. The output of such recent studies can provide information on the differences of total individuals in an area of differing types of forests (Abdullah et al. 2016). Furthermore, understanding the value of carbon is useful to formulate policies and legal frameworks pertinent to forest conservation. In regards to this, the Endau Rompin National Park (NP) is one of the remaining large tracts of pristine lowland tropical rainforests with an enormous amount of undisturbed natural vegetation in Peninsular Malaysia (MOCAT 2016). Hence, the forest ecosystem services in the Endau Rompin NP are important to climate change mitigation, acting as a carbon sink and $\mathrm{CO}^{2}$ scrub. Nonetheless, the amount of carbon stock present in a Dipterocarp forest like the Endau Rompin NP remains unknown for monitoring purposes (Laily, research officer, JNPC, pers. comm. 11 November 2015).

In terms of carbon valuation, the value of ecosystem services, such as carbon sequestration, is a reflection of what we, as a society, are willing to trade-off to conserve these natural resources (Kumar 2010). More importantly, the importance of the ecosystem towards society is realised through these indications (O'Garra 2007). On a global scale, this comprises carbon stock and reduced emissions from reduced deforestation (Wich et al. 2011). Hence, the objective of this paper was to determine the economic value of carbon stock and carbon sequestration in a dipterocarp tree dominated forest. The methods to determine carbon stock include forest inventories with allometric tree biomass regression models (Foody et al. 2001; Gonçalves et al. 2017; Lu 2005). Hence, such data is important for managing forested areas for reducing and mitigating $\mathrm{CO}^{2}$ emission (Van Breugel et al. 2011).

\section{MATERIALS AND METHODS}

\section{STUDY AREA}

The Endau Rompin NP is located in the southern part of Peninsular Malaysia. It is located between latitudes $2^{0}$ $34^{\prime} \mathrm{N}$ and longitude $103^{\circ} 11^{\prime} \mathrm{E}$ at $428 \mathrm{~m}$ above sea level. The size of the area is approximately 48,905 ha. There are two entry points into it, namely, Endau Rompin Peta at the Mersing district and Endau Rompin Selai at the Segamat district. The Endau Rompin NP is an area of mega-microbial diversity that is the second largest in the country after the Pahang NP. The forest in the Endau Rompin NP is dominated by lowland mixed dipterocarp forests, with an elevation of less than $300 \mathrm{~m}$ and for the hill dipterocarp forests it is more than $300 \mathrm{~m}$ (UNDP 2008). The geology of this park consists of the earliest known volcanic outpouring referred to as 'ash flow eruption' formed some 280 million years ago (Zakaria 2008). Many unique landforms and shapes of rocks have much to do with the forces of water (Malayan Nature Society 1988). The mean annual temperature is around $27^{\circ} \mathrm{C}$, with an annual rainfall between 2000 and above $3000 \mathrm{~mm}$ (Tho 1988). Compact layered trees keep this park area moistened throughout the year (UNDP 2008).

\section{DATA COLLECTION}

All forest parameters were recorded individually; they were the diameter at breast height (dbh), the tree height and tree species for ground forest inventory purposes in Endau Rompin Peta. The data collection was conducted in May 2016 for two weeks. The species identification was made by the forester. The purposive sampling technique 
was utilized to select six plots in Endau Rompin Peta. The size of each rectangular plot was $50 \times 20 \mathrm{~m}$ or 0.1 ha. Each plot was further divided into five subplots of $10 \times 20$ $\mathrm{m}$ to facilitate the data collection. The plots were chosen based on the accessibility in the forest and compatibility of trees. In addition, the sampling of trees was conducted in the virgin part of the jungle also known as the core zone, instead at the other areas gazetted as conservation zone and visitor zone by the Johor NP Corporation in its management plan, JNPC (2016) to cater for areas with large variations in tree species. With this, it was assumed that the plots chosen would represent the tree species in Endau Rompin NP. The first two plots were done at 51 $\mathrm{m}$ above the ground, the third and fourth plots (c and d) at $32 \mathrm{~m}$ above ground, whilst the last two plots (e and f) at 817 to $827 \mathrm{~m}$ above the ground. The distance between one plot two another was $10 \mathrm{~m}$. In terms of selection of trees in each plot, based on purposive sampling technique only trees with DBH greater than $15 \mathrm{~cm}$ were selected.

In terms of choosing the number of plots that meets the requirement for a ground forest inventory, in general, for a 1 ha forest size, 10 plots of $50 \times 20 \mathrm{~m}$ or 0.1 ha each should be chosen. Since the sampling area of study was 0.6 ha a total of 6 plots were chosen. Besides, the number of sample collected varied across the six plots. The numbers of trees in plot 1 were 24 trees, plot 2: 18 trees, plot 3: 30 trees, plot 4: 37 trees, plot 5: 42 trees, plot 6: 33 trees or in total 184 trees were sampled. The trees chosen were those with DBH greater than $15 \mathrm{~cm}$. All trees which were more than $15 \mathrm{~cm}$ in DBH in the plot were recorded. However, trees with DBH less than $15 \mathrm{~cm}$ were not chosen since the sampling area was chosen at the virgin part of the forest in Endau Rompin NP, whereby based on the management office of Endau Rompin NP the majority of the trees there are with DBH greater than 15 $\mathrm{cm}$. Hence, the number of trees with DBH less than 15 $\mathrm{cm}$ was assumed to be minimal. This implied that even by excluding the trees with DBH less than $15 \mathrm{~cm}$ the bias on the carbon stock value was minimal. Hence, the scope of the study was channelled to trees categorized for commercial values only which were trees with DBH between 15 - 44 cm; as Awang Noor and Ismail (2012) suggested logging should only be done on trees with commercial values i.e. those with DBH between (greater than $44 \mathrm{~cm})$.

\section{ESTIMATION OF ABOVEGROUND AND BELOWGROUND} FOREST BIOMASS

In terms of the specific measurement of the biomass, the following are the detailed discussions on the formulas chosen to calculate the aboveground biomass (AGB), belowground biomass (BGB) and other carbon components (living biomass, deadwood/coarse woody debris, litter and the remaining which was stored in the soil). In this study, the aboveground biomass was calculated using the allometric equations developed by Chave et al. (2005) for dipterocarp forests:

$$
\begin{aligned}
\mathrm{Wt}= & \rho^{*} \exp (-1.499+2.148 * \ln (\mathrm{D})+0.207 * \\
& (\ln (\mathrm{D})) 2-0.0281 *(\ln (\mathrm{D}))
\end{aligned}
$$

where $\mathrm{D}$ is the stem diameter at breast height and $\rho$ is the wood density $\left(\mathrm{g} / \mathrm{cm}^{3}\right)$.

On the other hand, the BGB for both the root biomass of the living trees and soil carbon was calculated based on an assumption that the biomass for the BGB comprised $19 \%$ of the total biomass contained in a tree. The assumption was made based on the findings on the proportion for belowground biomass based on the Malaysian report in the FAO (2015b). Likewise, Dirocco (2012) used a relatively close percentage, $18 \%$, to measure the BGB in the case of an upper hill forest in Malaysia (Temengor Forest Reserve in Perak, Peninsular Malaysia).

Other carbon components included the living biomass in deadwood/coarse woody debris, litter and the remaining, which were stored in the soil. However, the carbon contained in these understory components is often ignored in biomass estimates because it only amounts to 1 to 2\% (Birdsey 1992; Rodrigue 2001). Similarly, we noticed that in Hamdan et al. (2014) work, the sum of the AGB and BGB amounted to $98 \%$ whilst the rest belonged to other components that amounted to only $2 \%$. Therefore, the present study assumed the proportion of other carbon components as $2 \%$ of the total biomass contained in the trees.

After that, two steps were employed to obtain the specific carbon content. Firstly, following Ekoungoulou et al. (2015) and Omar et al. (2014), the carbon content was multiplied by 0.47 by assuming that approximately $50 \%$ of the biomass of the $\mathrm{ABV}$ was made up of carbon as asserted by Basuki et al. (2009). Secondly, the carbon value was further divided by 1000 as calculated by Ekoungoulou et al. (2015) to obtain the actual carbon content.

The specific equation used to obtain the carbon stock was as follows:

$$
\begin{aligned}
\mathrm{W}_{\mathrm{t}}= & \rho^{*} \exp (-1.499+2.148 * \ln (\mathrm{D})+0.207 * \\
& \left.(\ln (\mathrm{D}))^{2}-0.0281 *(\ln (\mathrm{D}))^{2)}\right]^{*} 0.47 /[1,000]
\end{aligned}
$$

In the latter stage, subsequent to determining the carbon stock and sequestration, the monetary terms were determined by putting a suitable value based on per tonnes of carbon stored as well as sequestered (Guo et al. 2001; Ismail 1995; Patton et al. 2015). For example, the average price of US\$6 per t $\mathrm{CO}^{2}$ in the carbon market was used to determine the carbon sequestration value by Mohammed et al. (2010). A higher rate (178 Yuan or US\$23) per tonne of carbon sequestered $\left(\mathrm{CO}^{2}\right)$ was used by Wu et al. (2010) to value the forest carbon stock in the Badaling forest in China. On the same note, an average price for carbon offsets in 2012 was determined at AP = $7.8 \mathrm{US} \$ / \mathrm{tCO}^{2}$ based on the market value assessment of the forest trends' ecosystem market place on the state of the forest carbon markets (Peters-Stanley et al. 2013). In an even later study, Ninan and Kontoleon (2016) used three 
values in ranges of US\$10, \$20 and $\$ 33$ for $\mathrm{t} \mathrm{CO}^{2}$ to value the carbon sequestration in a forest in a protected area in India. Despite various figures having been used to value the carbon, the present study chose the average amount between USD5 (low) - USD9 (high) per tonne of $\mathrm{CO}^{2}$ as used by Jamal and Ahmad (2013) for the mixed dipterocarp forest in the Taman Negara, Pahang since the forest in the Endau Rompin NP is also categorised as mixed dipterocarp. Thus, the carbon price value was estimated at RM31 per tonne based on the exchange rate of USD1: MYR4.49, 2016.

Apart from all this, in the last part of the results and discussions, for purposes of comparison of the carbon stock and sequestration values with past studies, the study identified the 1 ha values by dividing the total value of carbon in 0.6 ha with 0.6 .

\section{DATA ANALYSIS}

The preliminary data analysis was conducted using the SPSS version 24 software. This involved re-categorized the timber species by family classification, DBH categories and height of the trees. Later, a simple regression analysis was conducted using Nlogit 4.0 statistical package software to determine the relationship between the carbon stock in respect to the DBH and height.

\section{RESULTS AND DISCUSSION}

Table 1 shows the contents of the aboveground carbon (AGC), belowground carbon (BGC) and carbon contained in other components in the Dipterocarp and Non-dipterocarp categories of trees in the Endau Rompin NP. In terms of the aggregate total carbon for the dipterocarp family, we see that Mersawa kuning was the largest contributor at $20.41 \mathrm{Mg}$ (C) $0.6 \mathrm{ha}^{-1}$; whilst, the lowest was for Meranti tembaga at $1.42 \mathrm{Mg}(\mathrm{C}) 0.6 \mathrm{ha}^{-1}$. Whilst, for the nondipterocarp family the largest contribution came from the Medang species at $29.52 \mathrm{Mg}(\mathrm{C}) 0.6 \mathrm{ha}^{-1}$; whilst, the lowest aggregate share was from Kerdas at $0.08 \mathrm{Mg}$ (C) $0.6 \mathrm{ha}^{-1}$.

On the other hand, the finding of the average carbon stock in Table 1 shows that, the largest contributing tree species towards carbon sequestration disregarding the number of trees was Resak at $2.36 \mathrm{Mg}$ (C) $0.6 \mathrm{ha}^{-1}$; whilst, the lowest was Damar hitam at $0.23 \mathrm{Mg}$ (C) $0.6 \mathrm{ha}^{-1}$ for the dipterocarp family. Whereas, for the non-dipterocarp family, the largest average share came from Kedondong at $2.56 \mathrm{Mg}$ (C) $0.6 \mathrm{ha}^{-1}$; whilst, the lowest was from Kerdas at $0.08 \mathrm{Mg}(\mathrm{C}) 0.6 \mathrm{ha}^{-1}$. Overall, the total carbon stock amounted to $133 \mathrm{Mg}(\mathrm{C}) 0.6 \mathrm{ha}^{-1}$ for aboveground, $32 \mathrm{Mg}$ (C) $0.6 \mathrm{ha}^{-1}$ for belowground and $3 \mathrm{Mg}$ (C) $0.6 \mathrm{ha}^{-1}$ for the other components; in total, $169 \mathrm{Mg}(\mathrm{C}) 0.6 \mathrm{ha}^{-1}$.

Table 2 shows that for AGC, BGC and other components, an increase in the DBH category followed by a proportional increase in the carbon content. For example, we see for the $\mathrm{AGC}$, there was a continuous increase from $0.19 \mathrm{Mg}(\mathrm{C})$ $0.6 \mathrm{ha}^{-1}$ for the DBH between 15 and $30 \mathrm{~cm}$ to $2.84 \mathrm{Mg}(\mathrm{C})$ $0.6 \mathrm{ha}^{-1}$ for the $\mathrm{DBH}>60 \mathrm{~cm}$. Additionally, as expected, the values for the AGC were greater than for the BGC and other components. A clear picture on the earlier discussions is available in Figure 1.

\section{SIMPLE EXPONENTIAL AND LINEAR REGRESSION}

Figure 2 shows the allometric equation derived from the simple exponential and linear regression analysis. The simple exponential regression was conducted for all the equations except for AGC vs BGC. The coefficient of determination $\left(\mathrm{R}^{2}\right)$ value for each of the equations in the figure vindicated as to what extent the variation in the dependent variable (x-Axis) was explained by the changes in the independent variable (Y-Axis) in percentage. For example, the $\mathrm{R}^{2}$ value for the first equation for AGC vs BGC was 1 or in percentage, $100 \%$. This implied that a $1 \%$ unit change in the BGC would change 1 unit in the AGC. This relationship was expected since this study assumed that the BGB was assumed as a proportion amounting to $20 \%$ of the total biomass. In the second allometric equation (DBH vs AGC), we see that the $\mathrm{R}^{2}$ value was high $(0.81$ or $81 \%)$. This implied that the higher DBH would have more AGC content. Next, in terms of Height vs AGC, we see that the $\mathrm{R}^{2}$ value was lower at 0.6 or $60 \%$. An upward slope in the figure vindicated the proportional relationship between the height and AGC content. A lower $\mathrm{R}^{2}$ did not mean that the higher trees necessarily had more AGC content as in some of the cases where the DBH differed.

In the final allometric equation between DBH and Height, the $\mathrm{R}^{2}$ value was 0.62 ; in other words, $62 \%$ of the differences in height were explained by the DBH of the trees. This is true since higher trees may not necessarily have a higher DBH size.

The discussion in Table 3 was based on living and non-living components. The living components included the AGC and BGC. The total value amounted to RM5,186 or $\$ 1,155$ based on 0.6 ha. Later, the value was extrapolated to 1 ha, thus resulting in RM8,643 or $\$ 1,925$ based on 1 ha. The non-living components included other components with a value of RM126 or $\$ 28$ based on 0.6 ha whilst RM189 or $\$ 48$ was based on 1 ha. The total carbon price value (living nonliving) amounted to RM5,312 or $\$ 1,183$ based on 0.6 ha whilst RM8,832 or $\$ 1,967$ was based on 1 ha. Hence, based on the total area of the Endau Rompin NP, the total carbon sequestration value in monetary terms was $(48,905$ ha $\times$ RM8,832) = RM431,928,960 or $\$ 96,197,987$.

On the other hand, the total $\mathrm{CO}^{2}$ sequestrated value in the dipterocarp forest amounted to $620 \mathrm{t} \mathrm{CO}^{2} 0.6 \mathrm{ha}^{-1} \mathrm{ha}$ using a conversion proportion from $\mathrm{t} \mathrm{C} \mathrm{ha-1} \mathrm{to} \mathrm{tCO}^{2} \mathrm{ha}^{-1}$ (1:3.7) as employed by Lydia (2014). Later, the carbon sequestration value for 0.6 ha was prorated to 1 ha, thus resulting in 1,040 $\mathrm{t} \mathrm{CO}^{2} \mathrm{ha}^{-1}$. Hence, the value was estimated at RM19,220 or $\$ 4,340$ based on 0.6 ha whilst RM32,240 or $\$ 7,280$ was based on 1 ha.

\section{COMPARISON OF CARBON STOCK}

The carbon stock found in this study was compared with recent studies conducted in the dipterocarp forests similar 
TABLE 1. Carbon volume by species

\begin{tabular}{|c|c|c|c|c|c|c|c|}
\hline Local name & Scientific name & $\begin{array}{l}\text { No. of } \\
\text { trees }\end{array}$ & $\begin{array}{c}\text { AGC, } \\
\mathrm{Mg}(\mathrm{C}) \\
0.6 \mathrm{ha}^{-1}\end{array}$ & $\begin{array}{l}\text { BGc, } \mathrm{Mg} \\
\text { (C) } 0.6 \mathrm{ha}^{-1}\end{array}$ & $\begin{array}{c}\text { Carbon } \\
\text { in other } \\
\text { components } \\
\mathrm{Mg}(\mathrm{C}) \\
0.6 \mathrm{ha}^{-1}\end{array}$ & $\begin{array}{c}\text { Total } \\
\text { Carbon } \\
\mathrm{Mg}(\mathrm{C}) \\
0.6 \mathrm{ha}^{-1}\end{array}$ & $\begin{array}{l}\text { Average } \\
\text { Carbon } \\
\mathrm{Mg}(\mathrm{C}) \\
0.6 \mathrm{ha}^{-1}\end{array}$ \\
\hline \multicolumn{8}{|l|}{ Dipterocarp } \\
\hline Mersawa kuning & Anisoptera laevis Ridley & 17 & 16.12 & 3.88 & 0.41 & 20.41 & 1.20 \\
\hline Resak & Vatica maingayi & 8 & 14.94 & 3.59 & 0.38 & 18.90 & 2.36 \\
\hline Keruing kipas & Dipterocarpus sp. & 12 & 11.73 & 2.82 & 0.30 & 14.85 & 1.24 \\
\hline Kapur & Dryobalanops aromatica & 7 & 6.66 & 1.60 & 0.17 & 8.44 & 1.20 \\
\hline Meranti rambai daun & Shorea sp. & 6 & 3.50 & 0.84 & 0.09 & 4.43 & 0.74 \\
\hline Merawan jangkang & Hopea nervosa King & 2 & 1.16 & 0.28 & 0.03 & 1.46 & 0.73 \\
\hline Meranti sarang punai & Shorea parvifolia Dyer & 4 & 2.34 & 0.56 & 0.06 & 2.97 & 0.74 \\
\hline Meranti tembaga & Shorea leprosula Miq. & 1 & 1.12 & 0.27 & 0.03 & 1.42 & 1.42 \\
\hline Damar hitam & Shorea sp. & 8 & 1.42 & 0.34 & 0.04 & 1.80 & 0.23 \\
\hline Sub-total & & $\begin{array}{c}65 \\
(35.5 \%)\end{array}$ & 58.99 & 14.19 & 1.49 & 74.67 & \\
\hline \multicolumn{8}{|l|}{ Non-Dipterocarp } \\
\hline Medang & Litsea costata (Blume) Boerl. & 50 & 23.32 & 5.61 & 0.59 & 29.52 & 0.59 \\
\hline Simpoh gajah & Dillenia reticulata King & 7 & 14.06 & 3.38 & 0.36 & 17.79 & 2.54 \\
\hline Kelat & Syzygium sp. & 20 & 12.19 & 2.93 & 0.31 & 15.43 & 0.77 \\
\hline Kedondong & Canarium sp. & 3 & 6.07 & 1.46 & 0.16 & 7.69 & 2.56 \\
\hline Nyatoh taban merah & Palaquium sp. & 10 & 2.68 & 0.64 & 0.07 & 3.39 & 0.34 \\
\hline Ipoh & Antiaris toxicaria Lesch. & 2 & 2.50 & 0.60 & 0.06 & 3.16 & 1.58 \\
\hline Sesenduk & $\begin{array}{l}\text { Endospermum diadenum (Miq.) } \\
\text { Airy Shaw }\end{array}$ & 1 & 1.65 & 0.39 & 0.04 & 2.08 & 2.08 \\
\hline Kandis & Garcinia dioica & 2 & 3.30 & 0.79 & 0.08 & 4.18 & 2.09 \\
\hline Bintangor & Calophyllum sp. & 2 & 2.04 & 0.49 & 0.05 & 2.58 & 1.29 \\
\hline Mempening & Lithocarpus lucidus (Roxb.) Rehder & 3 & 3.37 & 0.81 & 0.08 & 4.27 & 1.42 \\
\hline Terap & $\begin{array}{l}\text { Artocarpus elasticus Reinw. Ex } \\
\text { Blume }\end{array}$ & 3 & 1.57 & 0.38 & $\begin{array}{l}0.04 \\
0.03\end{array}$ & $\begin{array}{l}1.98 \\
1.30\end{array}$ & $\begin{array}{l}0.66 \\
1.30\end{array}$ \\
\hline Sebasah daun besar & Aporosa arborea & 1 & 1.02 & 0.25 & & & \\
\hline Pulai & Alstonia scholaris & 5 & 0.66 & 0.16 & 0.02 & 0.84 & 0.17 \\
\hline Jelutong & Dyera costulata & 1 & 0.55 & 0.13 & 0.01 & 0.70 & 0.70 \\
\hline Keledang & Artocarpus rigidus & 2 & 0.69 & 0.16 & 0.02 & 0.87 & 0.44 \\
\hline Mempisang & Monocarpia marginalis & 1 & 0.41 & 0.10 & 0.01 & 0.52 & 0.52 \\
\hline Kayu arang & Diespyros sp. & 1 & 0.41 & 0.10 & 0.01 & 0.52 & 0.52 \\
\hline Mata ulat & Kokoona littoralis & 1 & 0.44 & 0.11 & 0.01 & 0.56 & 0.56 \\
\hline Rengas & Gluta sp. & 1 & 0.12 & 0.03 & 0.00 & 0.15 & 0.15 \\
\hline Kerdas & Pithecellobium bubalinum Benth. & 1 & 0.06 & 0.01 & 0.00 & 0.08 & 0.08 \\
\hline Sub-total & & $\begin{array}{c}119 \\
(65 \%)\end{array}$ & 77.12 & 18.55 & 1.96 & 97.62 & \\
\hline Total carbon & & $\begin{array}{c}184 \\
(100 \%)\end{array}$ & 133.48 & 31.96 & 3.37 & 168.73 & \\
\hline
\end{tabular}

TABLE 2. Average amount of carbon stock according to the DBH intervals $(\mathrm{cm})$

\begin{tabular}{cccc}
\hline $\begin{array}{c}\text { Row Labels } \\
(\mathrm{DBH} \text { interval (cm) }\end{array}$ & $\begin{array}{c}\text { AGC, } \\
\mathrm{Mg}(\mathrm{C}) \text { 0.6ha-1 }\end{array}$ & $\begin{array}{c}\text { BGC, Mg (C) } \\
0.6 \mathrm{ha}^{-1}\end{array}$ & $\begin{array}{c}\text { Carbon in other } \\
\text { components } \\
\mathrm{Mg}(\mathrm{C}) 0.6 \mathrm{ha}^{-1}\end{array}$ \\
\hline $15-30$ & 0.19 & 0.05 & 0.01 \\
$31-44$ & 0.49 & 0.12 & 0.01 \\
$45-50$ & 1.03 & 0.24 & 0.05 \\
$51-60$ & 1.55 & 0.36 & 0.04 \\
$>60$ & 2.84 & 0.69 & 0.07 \\
\hline
\end{tabular}




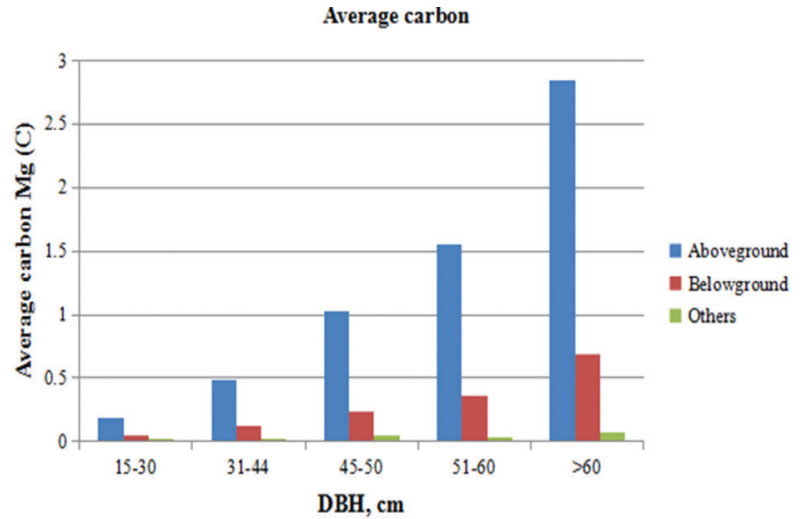

FIGURE 1. Average of the carbon stock for the study area
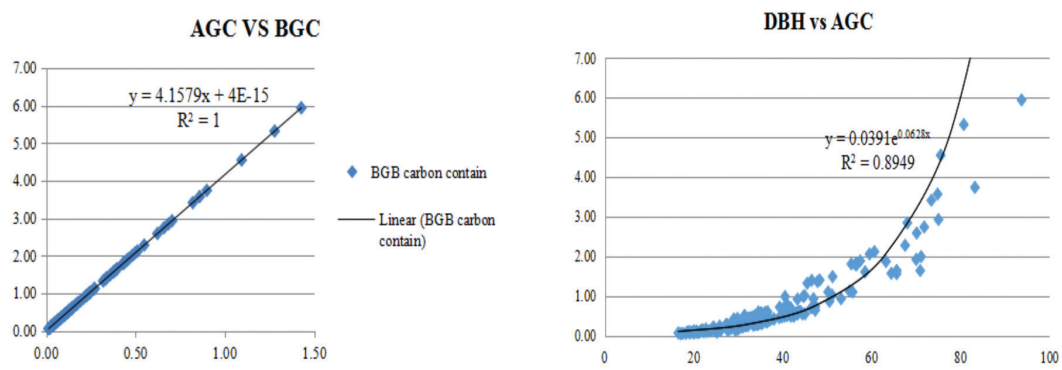

Height VS AGC
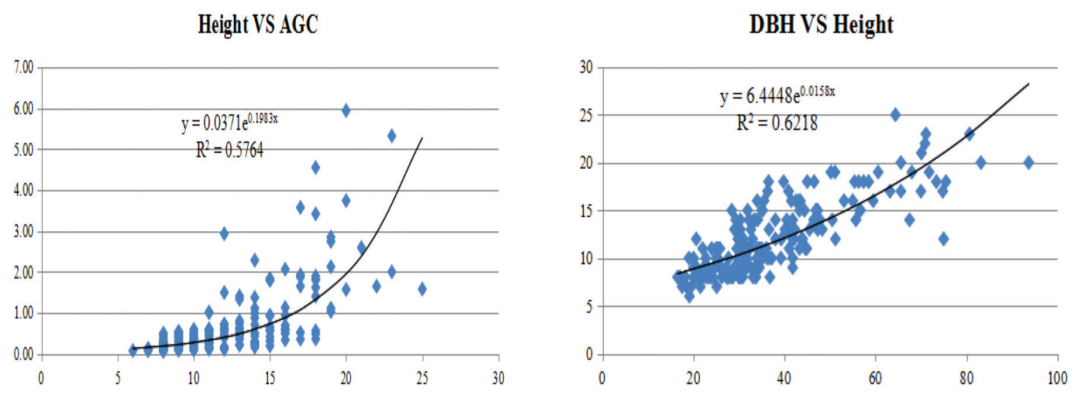

FIGURE 2. Allometric equations

TABLE 3. Carbon stock value in 2016

\begin{tabular}{cccc}
\hline Size of plot & Biomass, $\mathrm{Mg}(\mathrm{C})$ ha $^{-1}$ & Value (RM) & Value (USD) \\
\hline 0.6ha & AGC & & \\
1ha & 133 & 4,180 & 931 \\
& 222 & 6,977 & 1,554 \\
0.6 ha & BGC & & \\
1ha & 32 & 1,006 & 224 \\
0.6 ha & 53 & 1,666 & 371 \\
& Living- AGC+BGC & 5,186 & 1,155 \\
1ha & 165 & & 1,925 \\
& Living biomass-AGC+BGC & 8,643 & \\
0.6ha & 275 & & 28 \\
1ha & Non- living- Litter & & 42 \\
& 4 & 126 & 1,183 \\
0.6 ha & 6 & 189 & 1,967 \\
1ha & Living + Non living & 5,312 & \\
\hline
\end{tabular}

Exchange rate in 2016 (1USD: 4.49 MYR); carbon price = USD 7 or RM 31 per ton 
to the context of this research in Malaysia, namely, studies performed by Dirocco (2012) and Hamdan et al. (2014) specifically, and land use generally is crucial in recent days because forests play major roles in balancing terrestrial carbon and contribute to the mitigation of global warming and climate change. Consequent to the awareness of climate change, reducing emission from deforestation and forest degradation, and conservation (REDD+ at the Temenggor Forest Reserve and in the state of Pahang in Malaysia. The study found that the carbon stock values found in these studies $\left(208.8 \mathrm{Mg}(\mathrm{C}) \mathrm{ha}^{-1} ; 238.16 \mathrm{Mg}\right.$ (C) $\left.\mathrm{ha}^{-1}\right)$ were lower compared to this study $\left(281 \mathrm{Mg}(\mathrm{C}) \mathrm{ha}^{-1}\right)$. Also, it was higher than the value attained in a study conducted at the Malua Forest Reserve, Lahad Datu which found an average carbon stock of $167.9 \mathrm{Mg}(\mathrm{C}) \mathrm{ha}^{-1}$ (Saner et al. 2012).

On the other hand, the findings from this study were also higher as compared to some of the studies carried out in Southeast Asian countries conducted in dry inland forests; therefore, we excluded comparisons with the mangrove and peat swamp forests. For example, the value was higher than the value found for the primary forest in the Jambi Province amounting to $161 \mathrm{Mg}$ (C) ha-1 (Murdiyarso \& Wasrin 1995) and a study in a dipterocarp forest in Mindanao, Philippines amounting to $258 \mathrm{Mg}$ (C) ha-1 (Lasco et al. 2016). However, one of the possible reasons for the higher carbon stock value in this study is because only trees with at least a $15 \mathrm{~cm}$ diameter were chosen unlike in past studies mentioned before that had a lower DBH cutting point.

Hence, using the same carbon price per tonne, it could be expected that the carbon stock value in the Endau Rompin NP would be the highest, too.

\section{CONCLUSION}

It can be concluded from the findings, that the carbon stock of the forest in the Endau Rompin NP plays a potential role as a carbon sink that diminishes outflows of greenhouse gases and mitigates the climate change in the world. As compared to other tropical forests like the dry inland forests in Southeast Asia, we see that the carbon stock in the Endau Rompin NP was found to be higher. However, one of the possible explanations for this is that only trees with the DBH greater than $15 \mathrm{~cm}$ were chosen unlike in other studies where even trees with the DBH greater than $1 \mathrm{~cm}$ were chosen. The highest carbon content found in abundance and in the dominant species in the study, area was in Medang (Litsea costata Boerl). The results from the study showed that higher diameter classes contributed a large proportion of the carbon stock as well as carbon value. One of the main limitations in this study was that the carbon stock calculation did not take into account the carbon contents in deadwood and soil carbon due to measurement difficulties. Findings on carbon stock and carbon sequestration are important to provision crucial information on carbon credits to the park management to justify forest conservation efforts in the park. Recommendations for further studies should consider combining the findings based on the ground forest inventory in this study with the findings using remote sensing. This is important to get a more accurate result on the carbon stock in the national park.

\section{ACKNOWLEDGEMENTS}

This research was funded by the Research Management Centre, Universiti Putra Malaysia.

\section{REFERENCES}

Abdullah, H., Awang Noor, A.G. \& Hanum, I.F. 2016. Species diversity and stumpage valuation of timber resources at Pasir Tengkorak Forest Reserve, Langkawi, Kedah. Sains Malaysiana 45(3): 355-363.

Awang Noor, A.G. \& Ismail, M. 2012. Estimating the stumpage value of some timber species of $\mathrm{Sg}$. Enam Basin. Proceedings of the 2nd Temenggor Scientific Expedition. Petaling Jaya: Pulau Banding Foundation. pp. 37-45.

Basuki, T.M., van Laake, P.E., Skidmore, A.K. \& Hussin, Y.A. 2009. Allometric equations for estimating the above-ground biomass in tropical lowland Dipterocarp forests. Forest Ecology and Management 257(8): 1684-1694. doi:10.1016/j. foreco.2009.01.027.

Birdsey, R.A. 1992. Carbon Storage and Accumulation in the United States Forest Ecosystems. Washington, DC: U.S.

Busch, J. \& Engelmann, J. 2016. The Future of Forests: Emissions from Tropical Deforestation With and Without a Carbon Price, 2016-2050 - Working Paper 411. Center for Global Development. https://www.cgdev.org/publication/futureforests-emissions-tropical-deforestation-carbon-price.

Chave, J., Andalo, C., Brown, S., Cairns, M.A., Chambers, J.Q., Eamus, D., Fölster, H., Fromard, F., Higuchi, N., Kira, T., Lescure, J.P., Nelson, B.W., Ogawa, H., Puig, H., Riéra, B. \& Yamakura, T. 2005. Tree allometry and improved estimation of carbon stocks and balance in tropical forests. Oecologia 145(1): 87-99.

Dirocco, T.L. 2012. A thorough quantification of tropical forest carbon stocks in Malaysia. In Carbon Stocks of Tropical Forests. University of California, Berkeley Environmental Sciences. pp. 1-18.

Ekoungoulou, R., Niu, S., Loumeto, J.J., Ifo, A.S., Bocko, E.Y., Koula Mikieleko, F.E., Mpane Guiekisse, E.D., Senou, H. \& Liu, X. 2015. Evaluating the carbon stock in above-and below- ground biomass in a Moist Central African Forest. Applied Ecology and Environmental Sciences 3(2): 51-59. doi:10.12691/aees-3-2-4.

FAO. 2015a. Global Forest Resources Assessment 2015. Desk Reference.

Foody, G.M., Cutler, M.E., Mcmorrow, J., Pelz, D., Tangki, H., Boyd, D.S. \& Douglas, I.A.N. 2001. Mapping the biomass of Bornean tropical rain forest from remotely sensed data estimation and mapping. Global Ecology and Biogeography 10(4): 379-387.

Malayan Nature Society. 1988. Endau Rompin: A Malaysian Heritage. Kuala Lumpur: Malayan Nature Society.

Gonçalves, F., Treuhaft, R., Law, B., Almeida, A., Walker, W., Baccini, A., dos Santos, J.R. \& Graca, P. 2017. Estimating aboveground biomass in tropical forests: Field methods 
and error analysis for the calibration of remote sensing observations. Remote Sensing 9(1): 47. doi:10.3390/ rs9010047.

Gorte, R.W. 2009. Carbon sequestration in forests. Congressional Research Service. doi:10.1079/PAVSNNR20094041.

Gullison, R.E., Frumhoff, P.C., Canadell, J.G., Field, C.B., Nepstad, D.C., Hayhoe, K., Avissar, R., Curran, L.M., Friedlingstein, P., Jones, C.D. \& Nobre, C. 2007. Tropical forests and climate policy. Science 316(5827): 11361631136986. doi:10.1126/science. 1136163.

Guo, Z., Xiao, X., Gan, Y. \& Zheng, Y. 2001. Ecosystem functions, services and their values - A case study in Xingshan County of China. Ecological Economics 38(1): 141-154. doi:10.1016/S0921-8009(01)00154-9.

Hamdan, O., Norsheilla, M.J.C., Ismail, P., Abdul Khalim, A.S. \& Samsudin, M. 2014. Assessing carbon pools in dipterocarp forests of Peninsular Malaysia. Conference on Tropical Resources and Sustainable Sciences.

Ismail, R. 1995. An economic evaluation of carbon emission and carbon sequestration for the forestry sector in Malaysia. Biomass and Bioenergy 8(5): 281-292. doi:10.1016/09619534(95)00022-4.

Jamal, O. \& Ahmad, M.Z. 2013. Who pays and who gets what from national parks protection? Case of Taman Negara in Malaysia. Jurnal Ekonomi Malaysia 47(2): 25-37.

JNPC. 2016. Management Plan of Endau-Rompin National Park, Johor (2016-2025).

Komiyama, A., Ong, J.E. \& Poungparn, S. 2008. Allometry, biomass, and productivity of mangrove forests: A review. Aquatic Botany 89(2): 128-137. doi:10.1016/j. aquabot.2007.12.006.

Kueh, J.H.R., Majid, N.M.A., Seca, G. \& Ahmed, O.H. 2013. Above ground biomass-carbon partitioning, storage and sequestration in a rehabilitated forest, Bintulu, Sarawak, Malaysia. Sains Malaysiana 42(8): 1041-1050.

Kumar, P. 2010. The Economics of Ecosystems and Biodiversity: The Ecological and Economic Foundations. Earthscan: London and Washington. pp. 1-422.

Lasco, R.D., MacDicken, K.G., Pulhin, F.B., Guillermo, I.Q., Sales, R.F. \& Cruz, R.V.O. 2016. Carbon stocks assessment of a selectively logged Dipterocarp forest and wood processing mill in the Philippines. Journal of Tropical Forest Science 18(4): 212-221.

Lu, D. 2005. Aboveground biomass estimation using Landsamt $\mathrm{TM}$ data in the Brazilian Amazon. International Journal of Remote Sensing 26(12): 2509-2525.

Lydia, S.M. 2014. Quantification and economic valuation of carbon stock in the Matang Mangrove Forest Reserve in Perak. 17th Malaysian Forestry Conference. Kota Kinabalu. http://www.forest.sabah.gov.my/images/pdf/presentation material/MFC2014/Session5/Paper 5-2.pdf.

MOCAT. 2016. Endau Rompin National Park. http://www. malaysia.travel/en/es/places/states-of-malaysia/johor/endaurompin-national-park. Accessed on 25 December 2015.

Mohammed, S., Ferzandi, L. \& Hamilton, K. 2010. Metaphor no more: A 15-year review of the team mental model construct. Journal of Management 36(4): 876-910. doi:10.1177/0149206309356804.

Murdiyarso, D. \& Wasrin, U.R. 1995. Estimating land use change and carbon release from tropical forests conversion using remote sensing technique. Journal of Biogeography 22(4-5): 715-721. doi. 10.2307/2845974.
Nghiem, N. 2014. Optimal rotation age for carbon sequestration and biodiversity conservation in Vietnam. Forest Policy and Economics 38: 56-64. doi:10.1016/j.forpol.2013.04.001.

Niiyama, K., Kajimoto, T., Matsuura, Y., Yamashita, T., Matsuo, N., Yashiro, Y., Ripin, A. Kassim, A.R. \& Noor, N.S. 2010. Estimation of root biomass based on excavation of individual root systems in a primary dipterocarp forest in Pasoh Forest Reserve, Peninsular Malaysia. Journal of Tropical Ecology 26(3): 271-284. doi:10.1017/S0266467410000040.

Ninan, K.N. \& Inoue, M. 2013. Valuing forest ecosystem services: What we know and what we don't. Ecological Economics 93: 137-149. doi:10.1016/j.ecolecon.2013.05.005.

Ninan, K.N. \& Kontoleon, A. 2016. Valuing forest ecosystem services and disservices - Case study of a protected area in India. Ecosystem Services 20: 1-14. Retrieved from http:// dx.doi.org/10.1016/j.ecoser.2016.05.001.

O'Garra, T. 2007. Supplementary Livelihood Options for Pacific Island Communities: A Review of Experiences. The Foundation of the Peoples of the South Pacific International, Suva. http://www.reefbase.org/pacific/pub_A0000004147. aspx.

Omar, H. \& Hamzah, K.A. 2012. Aboveground Biomass and Carbon Stock Mapping and Changes Monitoring in the Forest of Peninsular Malaysia Using L-Band ALOS Palsar and JERS-1. Science Team meeting \#17 - Phase 3 JAXA TKSC/RESTEC HQ, March 27-29.

Omar, H., Norsheilla, M.J.C., Ismail, P., Abdul Khalim, A.S. \& Samsudin, M. 2014. Assessing carbon pools in dipterocarp forests of Peninsular Malaysia. Conference on Tropical Resources and Sustainable Sciences.

Patton, D., Bergstrom, J.C., Moore, R. \& Covich, A.P. 2015. Economic value of carbon storage in U.S. National Wildlife Refuge wetland ecosystems. Ecosystem Services 16: 94-104. doi:10.1016/j.ecoser.2015.10.017.

Peters-Stanley, M., Gonzales, G. \& Yin, D. 2013. Covering New Ground - State of the Forest Carbon Markets 2013. A report by Forest Trends' Ecosystem Marketplace. Washington DC, USA.

Rodrigue, J.A. 2001. Woody species diversity, forest and site productivity, stumpage value, and carbon sequestration of forests on mined lands reclaimed prior to the passage of the surface mining control and reclamation act of 1977. Master Thesis, Virginia Polytechnic Institute and State University (Unpublished).

Saner, P., Loh, Y.Y., Ong, R.C. \& Hector, A. 2012. Carbon stocks and fluxes in tropical lowland dipterocarp rainforests in Sabah, Malaysian Borneo. PLoS ONE 7(1): doi:10.1371/ journal.pone.0029642.

Siwar, C., Chinade, A.A., Mohamad, S. \& Isahak, A. 2016. Economic valuation of soil carbon sequestration services in Malaysia's forest sector: A review of possible approaches. Journal of Sustainability Science and Management 11(1): $14-28$

Tho. 1988. Endau-Rompin park management guidelines. In Endau Rompin. Kuala Lumpur: Malayan Nature Society.

UNDP. 2008. Enhancing Effectiveness and Financial Sustainability of Protected Areas in Malaysia. Retrieved from http://www.undp.org/content/dam/malaysia/docs/ Protected Areas ProDoc.pdf.

Uryu, Y., Mott, C., Foead, N., Yulianto, K., Budiman, A., Takakai, F., Nursamsu, Sunarto, Purastuti, E., Fadhli, N., Hutajulu, C.M.B., Jaenicke, J., Hatano, R., Siegert, F. \& Stüwe, M. 
2008. Deforestation, Forest Degradation, Biodiversity Loss and CO2 Emissions in Riau, Sumatra, Indonesia. WWF Indonesia Technical Report Jakarta Indonesia, pp. 1-80. http://assets.panda.org/downloads/riau_co2_report_wwf_ id_27feb08_en_lr_.pdf.

Van Breugel, M., Ransijn, J., Craven, D., Bongers, F. \& Hall, J.S. 2011. Estimating carbon stock in secondary forests: Decisions and uncertainties associated with allometric biomass models. Forest Ecology and Management 262(8): 1648-1657. doi:10.1016/j.foreco.2011.07.018.

Wang, Y. \& Wesche, K. 2016. Vegetation and soil responses to livestock grazing in Central Asian grasslands: A review of Chinese literature. Biodiversity and Conservation (iDiv) pp. 1-20. doi:10.1007/s10531-015-1034-1.

Wich, S., Riswan, Jenson, J., Refisch, J. \& Nellemann, C. 2011. Orangutans and the Economis of Sustainable Forest Management in Sumatra. UNEP/GRASP/PanEco/YEL/ ICRAF/GRID-Arendal. Norway: Birkeland Trykkeri AS.

Wu, S., Hou, Y. \& Yuan, G. 2010. Valuation of forest ecosystems goods and services and natural capital of the Beijing municipality. Unasylva 61: 28-36. http://www.fao.org. webtranslatewidget.systransoft.com/docrep/012/i1507e/ i1507e07.pdf

Zakaria, H. 2008. Geoheritage of Malaysia. In Geoheritage of East and Southeast Asia, edited by Mohd. Shafeea Leman, Reedman, A.J., Chen, S.P., Universiti Kebangsaan Malaysia. Institut Alam Sekitar dan Pembangunan; Coordinating Committee for Geoscience Programmes in East and Southeast Asia. Bangi: LESTARI, Universiti Kebangsaan Malaysia; Bangkok, Thailand: Coordinating Committee for Geoscience Programmes. http://www.ccop.or.th/download/pub/CCOPgeoheritage-book.pdf.
Nitanan Koshy Matthew, Ahmad Shuib*, Sridar Ramachandran \& Syamsul Herman Mohammad Afandi Institute of Agricultural and Food Policy Studies

Universiti Putra Malaysia, Putra Infoport 43400 UPM Serdang, Selangor Darul Ehsan Malaysia

Sridar Ramachandran, Syamsul Herman Mohammad Afandi \& Zaiton Samdin

Faculty of Economics and Management

Universiti Putra Malaysia

43400 UPM Serdang, Selangor Darul Ehsan

Malaysia

Ismail Muhammad \& Muhd Ekhzarizal Mohd Eusop Faculty of Forestry

Universiti Putra Malaysia

43400 UPM Serdang, Selangor Darul Ehsan

Malaysia

*Corresponding author; email: mad.shuib@gmail.com

Received: 31 March 2017

Accepted: 20 September 2017 